\title{
COMPARATIVE STUDY OF BIOETHANOL POTENTIALS PRODUCED FROM YAM PEELS AND BAMBARA NUT SHELLS
}

\author{
${ }^{*}$ A. Yusuf, C.M. Elinge ${ }^{1}$, A. Hannatu ${ }^{1}$ and D.S Senchi ${ }^{1}$ \\ 1. Department of Pure and Applied Chemistry, Kebbi State University of Science and \\ Technology, Aliero. \\ *Correspondence email: awalyusufmaitama@gmail.com
}

\begin{abstract}
In this study, Yam peels and Bambara nut shells were hydrolyzed with $0.25 \mathrm{~m}, 0.50 \mathrm{~m}, 1.00 \mathrm{~m}$, and $2.00 m$ concentration of dilute sulphuric acid $\left(\mathrm{H}_{2} \mathrm{SO}_{4}\right)$ respectively and the reducing sugar concentration were determined using the dinitrosalicylic acid (DNS) colorimetric method. The results revealed that there is no significant difference $(p<0.05)$ in the yields of the reducing sugar obtained from the two substrates at different treatment conditions. Confirmatory tests and other fuel properties such as; specific gravity, boiling point, flash point, pour point, cloud point, octane number FTIR and GCMS analysis were also determined in order to ascertained that the distillate produced were actually ethanol with respect to the standard from WHO/DPR and ASTM.
\end{abstract}

Keywords: Acid hydrolysis; Bambara nut shell; fermentation; DNSFTIR; GC/MS; ASTM; WHO; DPR. 


\section{INTRODUCTION}

Whether cost-effectively advanced or at different stages of advancement, most nations are facing with the difficulty of discarding and treatment of wastes. There are several ways of treating the wastes (e.g. by reducing its vastness or by recuperating and reprocessing it into useful substance) to meet sanitary standards. Ethanol fermented from renewable sources for fuel or fuel additives are known as bio-ethanol. One of the greatest tasks for humanity in the twenty-first century is that fossil fuels are depleting day by day and considered as limited and non-renewable energy. In addition, the availability of these non-renewable energy resources will certainly drop as a result of the escalation in energy demands and the limitation of energy resources. According to Croockes et al. (2006), the production of oil is expected to deteriorate in the next 10-100 years.

The long-time period blessings of the usage of discarded excesses as lignocellulosic feed stocks could be to bring collectively a sustainable strong waste control approach for a number of lignocellulosic waste materials, which contribute to the moderation in greenhouse gases through unrelenting carbon and nutrient recycling, lessen the capacity for water, air, and soil infection related to the land utility of organic waste materials, and to boost the feedstock supply of raw substances for the bioethanol industrialized enterprise (Rabah et al., 2011).

The purpose of this research work is to optimize and compare the potential of bioethanol produced from yam peels and Bambara nut shell.

\section{MATERIALS AND METHODS}

\section{Sample collection}

Samples of the Yam peels and Bambara nut shell were acquired from Kaboji, Mashegu Local Government Area, Niger State, Nigeria.

\section{Sample Preparation}

The samples were sundried clumsily for two weeks and grinded to powder using a mortar and pestle to upturn the surface area for hydrolysis process.

\section{Preparation of Reagents}

Exactly $1.40 \mathrm{ml}$ of concentrated $\mathrm{H}_{2} \mathrm{SO}_{4}$ was precisely measured and reassigned into $100 \mathrm{ml}$ volumetric flask and up to the mark using distilled water for preparation of $0.25 \mathrm{M}$. For $0.50 \mathrm{M}$, $1.00 \mathrm{M}$ and $2.00 \mathrm{M}$ about $2.80 \mathrm{ml}, 5.60 \mathrm{ml}$ and $11.10 \mathrm{ml}$ were to be precisely measured and reassigned into $100 \mathrm{ml}$ volumetric flask and made up to the mark using distilled water.

$2 \mathrm{M}$ Sodium hydroxide, exactly $80 \mathrm{~g}$ of $\mathrm{NaOH}$ was accurately measure and conveyed into $1000 \mathrm{~cm}^{3}$ volumetric flask and up to the mark using distilled water (Rabbah et al., 2011).

Dinitrosalicylic Acid (DNSA), 60ml of the $2 \mathrm{M} \mathrm{NaOH}$ was accurately measured and dispensed into a conical flask followed by addition of $3 \mathrm{~g}$ of DNSA into the conical flask. About $50 \mathrm{~g}$ of potassium sodium tartrate (Rochelle salt) were later weighed and dissolved into $100 \mathrm{ml}$ of 
distilled water. The potassium sodium tartrate salt solution will then be added to the DNSA solution and the mixture was made up to $200 \mathrm{ml}$ with distilled water (Sheikh et al., 2016).

\section{Experimental Design}

The experimental design were conducted using mat lab software using (RSM)

\begin{tabular}{lccc}
\hline Run Order & Concentration (M) & Time (min) & Temperature $\left({ }^{\mathbf{C}} \mathbf{C}\right)$ \\
\hline 1 & 0.25 & 80 & 100 \\
2 & 0.25 & 60 & 70 \\
3 & 0.25 & 105 & 70 \\
4 & 0.50 & 90 & 40 \\
5 & 0.50 & 60 & 100 \\
6 & 0.50 & 105 & 70 \\
7 & 0.50 & 75 & 60 \\
8 & 1.00 & 90 & 60 \\
9 & 1.00 & 105 & 40 \\
10 & 1.00 & 605 & 100 \\
11 & 1.00 & 80 & 80 \\
12 & 2.00 & 105 & 40 \\
13 & 2.00 & 75 & 70 \\
14 & 2.00 & 90 & 80 \\
15 & 2.00 & & 100 \\
\hline
\end{tabular}

\section{Preparation of standard curve}

The standard curve was calibrated by adding $2 \mathrm{ml}$ of DNSA reagent into $0.10,0.20,0.30,0.40$ and $0.50 \mathrm{ml}$ of glucose standard solution followed by heating over water bath for $5 \mathrm{~min}$. The solution would be allowed to cool in cold water before measuring the absorbance using UVvisible spectrophotometer at 540nm (Nair et al., 2017).

\section{Hydrolysis}

Each run involve $1 \mathrm{~g}$ of the Bambara nut shells in $250 \mathrm{ml}$ beaker, follow by addition of $150 \mathrm{ml}$ $\mathrm{H}_{2} \mathrm{SO}_{4}$ concentration as specified in the table 2.4. The mixture will then be heated and stirred concurrently over a magnetic stirrer for a period of time at particular temperature as specified in the matrix design table 2.4. After hydrolysis of the Bambara nut shells, a solution of sodium hydroxide was used to neutralize the $\mathrm{pH}$ within 4.5 to 6.0 (Mohd et al., 2017).

\section{Uv-spectrophotometer}

The quantitative determination of glucose for bio-ethanol production was done using the UVspectrophotometer at constant wavelength of $550 \mathrm{~nm}$, using distilled water as blank. UVspectrophotometer uses discrete wavelengths of light to determine the concentration of certain compounds in a sample. 


\section{Determination of Glucose content}

Spectroscopic method was employed in the determination of the glucose content present in the hydrolyzed samples using DNSA by the method reported by Ranken (1984), with a little modification which is briefly described as follows; $2 \mathrm{ml}$ of the DNSA reagent was added to $1 \mathrm{ml}$ of a sample. The mixture was then heated for about $5 \mathrm{~min}$ over a water bath, and was allowed to cool in cold water. The absorbance of the sample was obtained using UV-visible spectrophotometer at a wavelength of $540 \mathrm{~nm}$. The glucose concentration was obtained with the help of the glucose standard curve.

\section{Fermentation of the Hydrolyzed Samples}

Fermentation of the hydrolyzed yam peels and Bambara nut shells were carried out using a method described by Adeeyo et al., (2015) with some modifications.

After $p \mathrm{H}$ of the hydrolysed samples were regulated between 4.5-6.0 using sodium hydroxide solutions, about $1.0 \mathrm{~g}$ of yeast and $2.0 \mathrm{ml}$ of the hydrolyzed samples were added to $20 \mathrm{ml}$ of warm water which is shaken for about 5minutes to activate the yeast. This were added to $150 \mathrm{ml}$ of the hydrolyzed sample in a bottle and then closed tightly. The mixtures were then left for 96hours to ferment. The procedure will be repeated for $3.0 \mathrm{~g}, 5.0 \mathrm{~g}$ and $7.0 \mathrm{~g}$ of yeast respectively (Adeeyo $e t$ al., 2015).

\section{Instrumental Analysis}

The instrumental analysis was conducted at National Research Institute for Chemical Technology Zaria, Kaduna State, Nigeria.

While only Gc/Ms analysis was conducted at Shimadzu Training Center for Analytical Instruments (STC) Lagos.

\section{Percentage yield of the Samples}

The Percentage Yield of the samples was determined using the following equation.

Quantity of ethanol produced x Specific Gravity

Percentage Yield $=$

Amount of Sample used 
Journal DOI: 10.46654/ij.24889849

Vol. 6, Issue 10 (October, 2020) | www.ijaar.org

Article DOI: 10.46654/ij.24889849.e61012

\section{RESULTS AND DISCUSSIONS}

\section{Results}

Table 1: Percentage Glucose Yield

\begin{tabular}{lccccc}
\hline $\begin{array}{l}\text { Run } \\
\text { Order }\end{array}$ & $\begin{array}{c}\text { Concentration } \\
(\mathbf{M})\end{array}$ & $\begin{array}{c}\text { Time } \\
(\mathbf{m i n})\end{array}$ & $\begin{array}{c}\text { Temperature } \\
\left({ }^{\mathbf{}} \mathbf{C}\right)\end{array}$ & $\begin{array}{c}\text { Glucose Yield } \\
(\mathbf{A})\end{array}$ & $\begin{array}{c}\text { Glucose Yield } \\
(\mathbf{B})\end{array}$ \\
\hline 1 & 0.25 & 80 & 100 & 0.4512 & 0.4840 \\
2 & 0.25 & 60 & 70 & 0.2668 & 0.3928 \\
3 & 0.25 & 105 & 70 & 0.4864 & 0.4784 \\
4 & 0.50 & 90 & 40 & 0.2496 & 0.4100 \\
5 & 0.50 & 60 & 100 & 0.4872 & 0.4588 \\
6 & 0.50 & 105 & 70 & 0.2508 & 0.4808 \\
7 & 0.50 & 75 & 60 & 0.2976 & 0.3832 \\
8 & 1.00 & 90 & 60 & 0.1224 & 0.3940 \\
9 & 1.00 & 105 & 40 & 0.1688 & 0.3536 \\
10 & 1.00 & 105 & 100 & 0.4812 & 0.4812 \\
11 & 1.00 & 60 & 80 & 0.3160 & 0.4668 \\
12 & 2.00 & 80 & 40 & 0.4856 & 0.4352 \\
13 & 2.00 & 105 & 70 & 0.4868 & 0.4800 \\
14 & 2.00 & 75 & 80 & 0.4876 & 0.4816 \\
15 & 2.00 & 90 & 100 & 0.1996 & 0.4792 \\
\hline
\end{tabular}

Table 2: Physicochemical Characteristics of the Bioethanol Produced

\begin{tabular}{llll}
\hline Parameter & Sample (A) & Sample (B) & ASTM Standard \\
\hline Specific Gravity & 0.88000 & 0.9080 & $0.789-0.801$ \\
Boiling point & 69 & 65.0 & 78.2 \\
$p \mathrm{H}$ & 6.68 & 6.24 & $6.5-9.0$ \\
Appearance & $\begin{array}{l}\text { Cloudy, without any } \\
\text { particles }\end{array}$ & $\begin{array}{l}\text { Clear, without any } \\
\text { particles }\end{array}$ & $\begin{array}{l}\text { Clear, without any } \\
\text { particles }\end{array}$ \\
\hline
\end{tabular}

Table 3: Fuel Properties of Bioethanol Produced

\begin{tabular}{llll}
\hline Parameter & Sample (A) & Sample (B) & ASTM Standard \\
\hline Flash Point & 16.50 & 18.40 & $16.50-16.70$ \\
Octane Rating & 101 & 108 & 96 above \\
Pour Point & -7.40 & -7.80 & -5.0 \\
Cloud Point & -4.30 & -5.10 & -23 \\
\hline
\end{tabular}


International Journal of Advanced Academic Research (Sciences, Technology and Engineering)| ISSN: 2488-9849

Journal DOI: 10.46654/ij.24889849

Vol. 6, Issue 10 (October, 2020) | www.ijaar.org

Article DOI: 10.46654/ij.24889849.e61012

FTIR results of the Bioethanol produced

FTIR Analysis result of the bioethanol produced from sample A

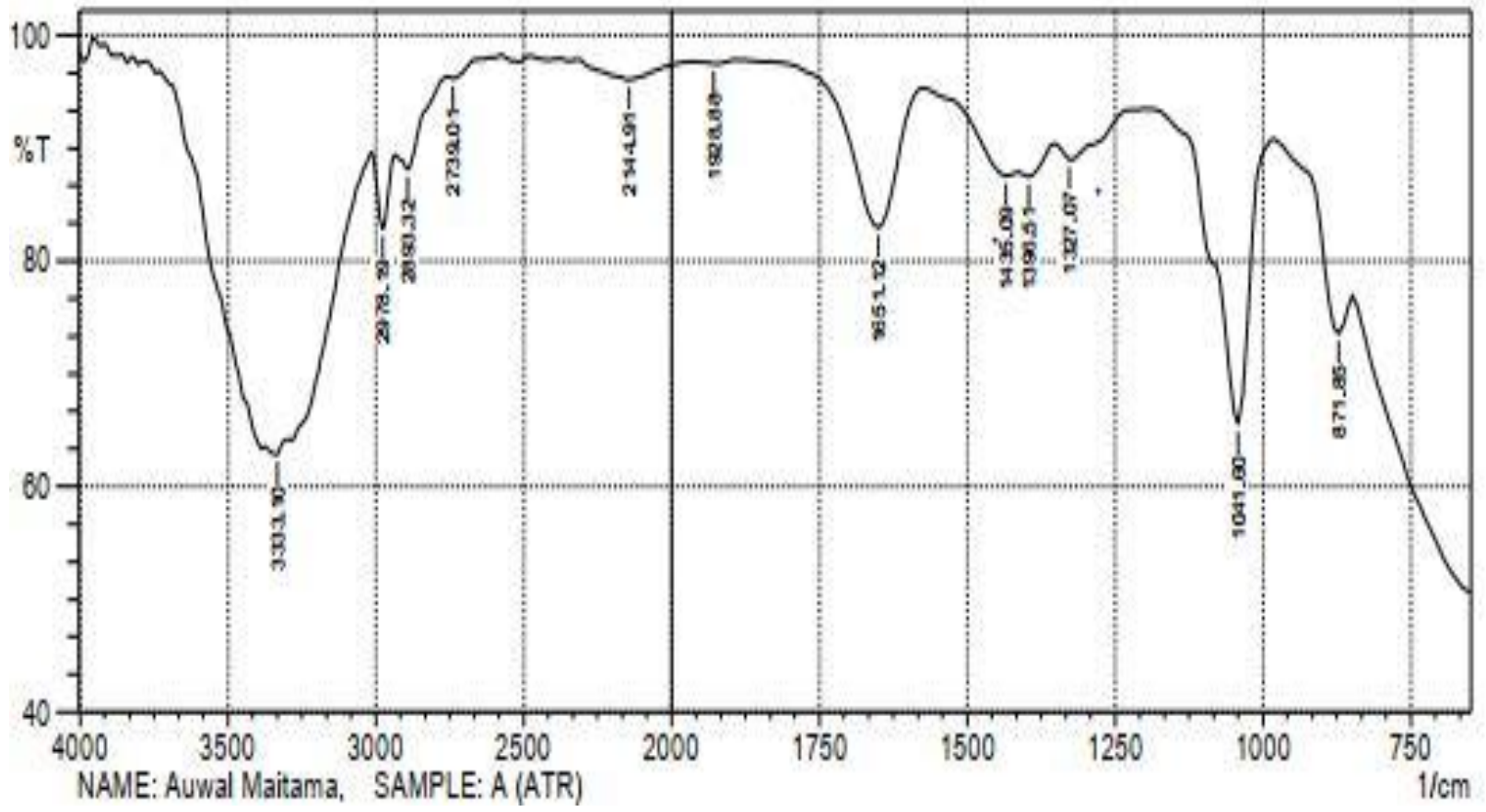

Fig (1).

FTIR Analysis result of the bioethanol produced from sample B

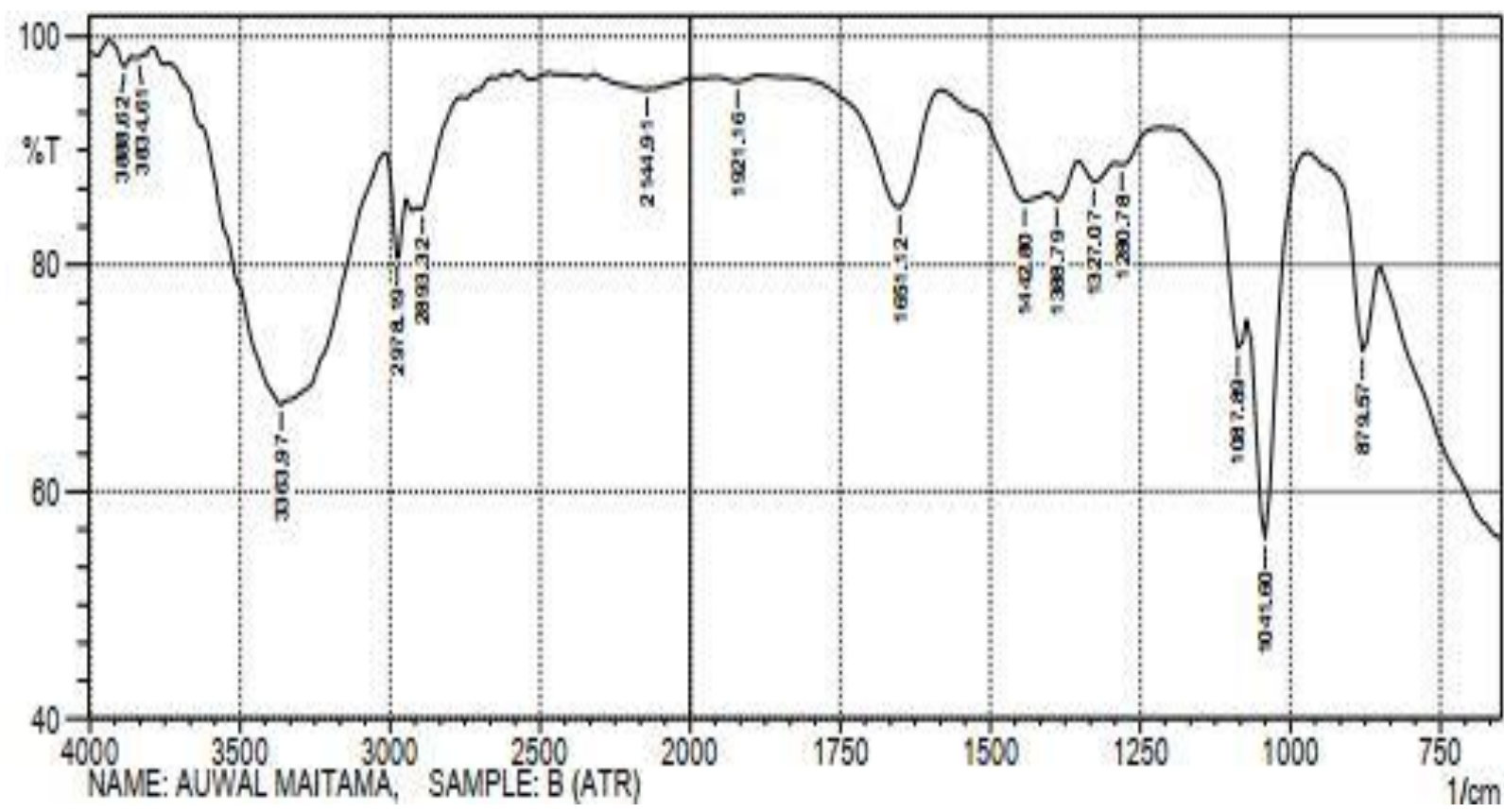

Fig (2). 
Journal DOI: 10.46654/ij.24889849

Vol. 6, Issue 10 (October, 2020) | www.ijaar.org

Article DOI: 10.46654/ij.24889849.e61012

\section{Results for Gc/Ms Analysis of Bioethanol produced.}

Gas chromatography and mass spectroscopy was conducted to determine the end product of the bioethanol which was present in the entire sample.

\section{GCMS Analysis result of the bioethanol produced from sample (A)}

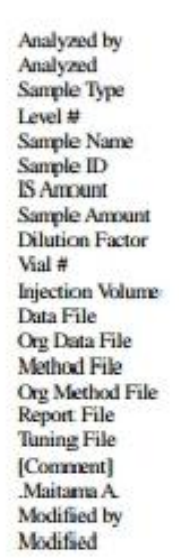

: SReonald lhias

: 8/3 1/2019 5:43:39 PM

: Unknown

$: 1$

$\therefore$ Maitama A.

. Maitama A.

$:[1]=1$

$: 1$

$: 1$

$: 1$
$: 1$
$: 1.00$

C.N030919, Maitama A.QGD

C.FOCMSsolution/Extract,_Maitama A.QGD

C.JOCMSsolution)Extract/Assay Ethanol.qgen

C.GOCMSsolutiondExtract|Assay Ethanol.qum

:CYCCMSsolution/System/1Tune 1/3111271900.ggt

:Admin

9/1/20195:48:23 PM

Sample Infomation

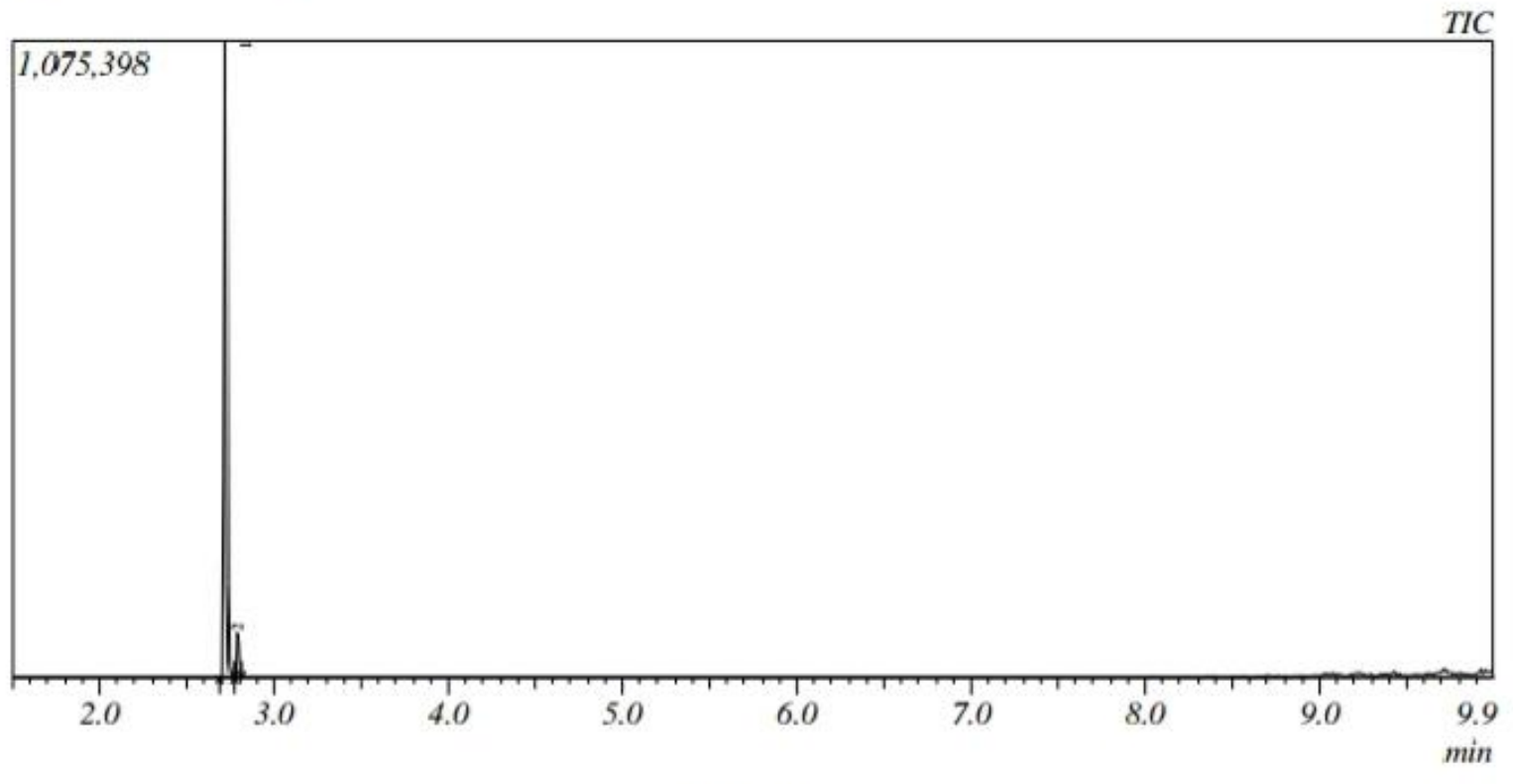

Fig (3).

Sample (A)

\begin{tabular}{llllll}
\hline $\begin{array}{l}\text { Line } \\
\text { Number }\end{array}$ & Compound Name & $\begin{array}{l}\text { Molecular } \\
\text { Formula }\end{array}$ & $\begin{array}{l}\text { Molecular } \\
\text { Weight }\end{array}$ & $\begin{array}{l}\text { Retention } \\
\text { Time }\end{array}$ & Base Peak \\
\hline 1 & Methoxymethane & $\mathrm{C}_{2} \mathrm{H}_{6} \mathrm{O}$ & 46 & 296 & 45.05 \\
2 & 2-Propanol & $\mathrm{C}_{3} \mathrm{H}_{8} \mathrm{O}$ & 60 & 482 & 45.05 \\
\hline
\end{tabular}


Journal DOI: 10.46654/ij.24889849

Vol. 6, Issue 10 (October, 2020) | www.ijaar.org

Article DOI: 10.46654/ij.24889849.e61012

\section{GCMS Analysis result of the bioethanol produced from sample B}

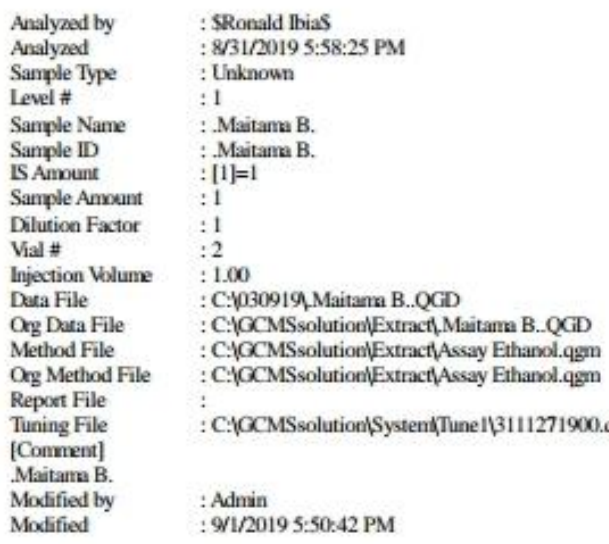

Sample Information

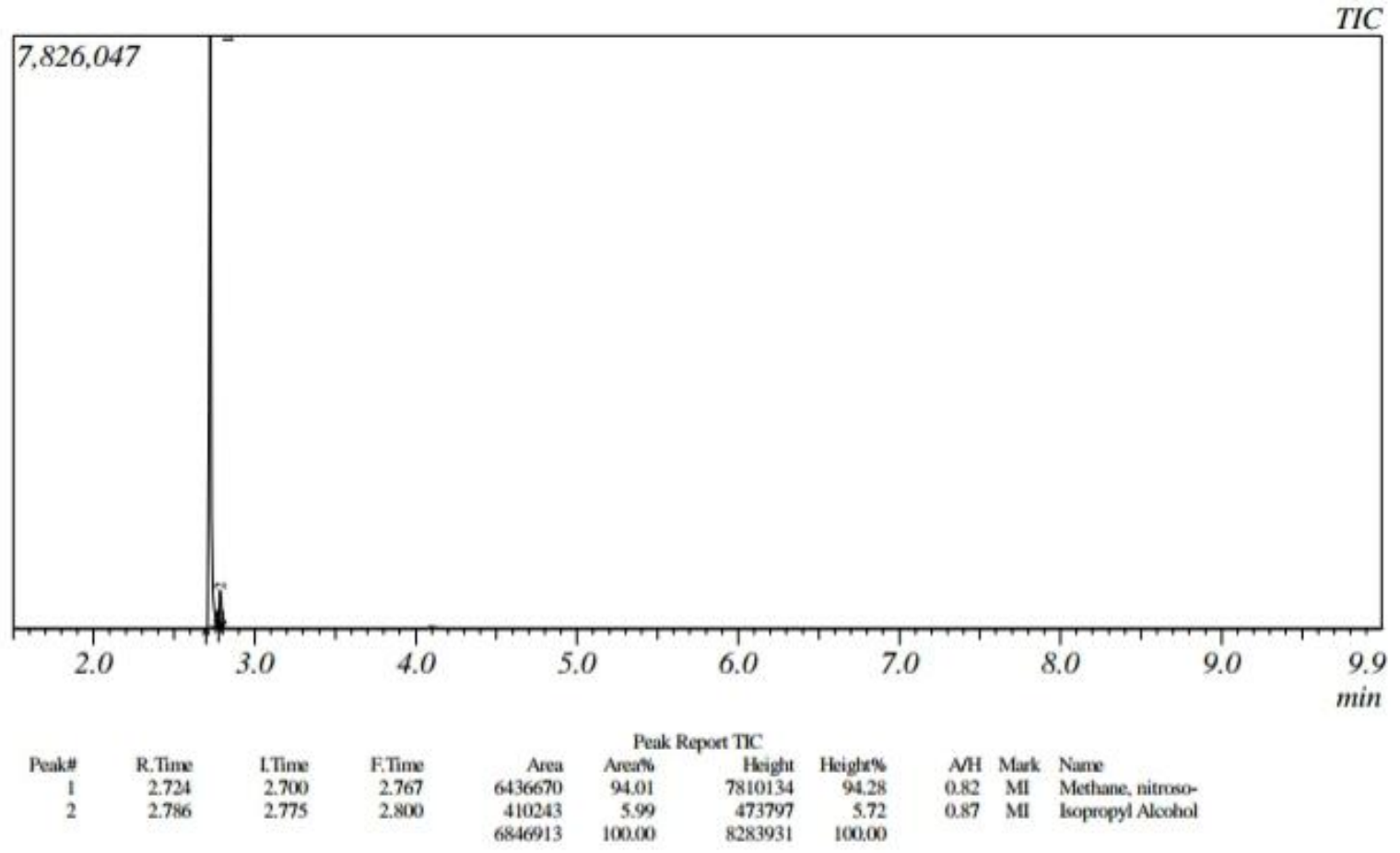

Fig (4).

Sample (B)

\begin{tabular}{llllll}
\hline $\begin{array}{l}\text { Line } \\
\text { Number }\end{array}$ & Compound Name & $\begin{array}{l}\text { Molecular } \\
\text { Formula }\end{array}$ & $\begin{array}{l}\text { Molecular } \\
\text { Weight }\end{array}$ & $\begin{array}{l}\text { Retention } \\
\text { Time }\end{array}$ & Base Peak \\
\hline 1 & Ethanol & $\mathrm{C}_{2} \mathrm{H}_{6} \mathrm{O}$ & 46 & 463 & 45.05 \\
2 & 2-Propanol & $\mathrm{C}_{3} \mathrm{H}_{8} \mathrm{O}$ & 60 & 482 & 45.05 \\
\hline
\end{tabular}

\section{Discussion}

Acid hydrolysis of Bambara nut shells and yam peels at different acid concentrations and ambient temperature showed an increase in glucose concentration with time (Table 1). The concentration of glucose was higher when the concentration acid for sample A and B were $2 \mathrm{M}$ at 
$70^{\mathrm{OC}}$ for the period of 75 minutes and $0.25 \mathrm{M} \mathrm{H}_{2} \mathrm{SO}_{4}$ at $100^{\mathrm{OC}}$ for the period of 80 minutes were used respectively. There was a slight drop in glucose concentration for the biomass when hydrolyzed at $1 \mathrm{M} \mathrm{H}_{2} \mathrm{SO}_{4}$ for both the samples. This could be ascribed to the actuality that at higher concentration of acid, glucose can be changed to levulinic acid and formic acid (Goh and Lee, 2010), which leads decline in glucose yield. These then suggest that uppermost glucose yield can be obtained at negligible acid concentration of $0.25 \mathrm{M}$ to $2.00 \mathrm{M} \mathrm{H}_{2} \mathrm{SO}_{4}$ which as well serves as the most advantageous $p \mathrm{H}$ condition for yeast to metabolise its substrate (Mosie et al., 2005). This corresponds with the findings of Abdullahi et al. (2014).

The fermentation was completed on the $5^{\text {th }}$ day as no observable change was noticed on the fermentation medium such as bubbles of $\mathrm{CO}_{2}$. These observation suggested that maximum ethanol production corresponds with observation of Piotrowski et al. (2011), following the method described by Hendriks, and Zeeman (2009). 39.5\% and 29.8\% ethanol was produced in hydrolysates A and B respectively by the end of fermentation. This corresponds with the findings of Mathew (2013).

The general shortcomings of batch fermentation described by Reed (2014), may also affect yield, thereby suggesting continuous fermentation which increase the yeast population by recycling and the removal of ethanol during the fermentation as a better method. Separating the ethanol from the fermentation liquid by partial distillation recovered about $50 \%$ ethanol by volume which was reported by Rittmann et al., (2008) on cassava waste. Additional distillation of the sample under controlled conditions could produce higher percentage of ethanol.

The specific gravity of the two samples being 0.88 and 0.91 were in total agreement with the standard obtained from ASTM range (0.78-0.85) it is noted that, the more the water content the higher the specific gravity of the liquid. And this indicates that it can be used as a solvent for chemicals and also in production of liquid detergents.It was observed that the boiling point which varies from $69^{\circ} \mathrm{c}$ (yam peels) to $65^{\circ} \mathrm{c}$ for (bambara nut shells) relate favorably with the standard boiling point of ethanol.

The $p \mathrm{H}$ of the two samples (yam peels and bambara nut shells) are 6.68 and 6.24 respectively, which implies that the experimental ethanol was neither acidic nor alkali. The $p \mathrm{H}$ below the specification can develop a risk for reflux.

The minimum temperature at which the fuel will ignite when exposed to an ignition sources. The results presented indicate that the flash point of the produced bioethanol was 21.50 and $19.60^{\circ} \mathrm{c}$ for yam peels and bambara nut shells respectively. This implies that the bioethanol produced is less flammable than the standard ethanol fuel (Soibam et al., 2017).

The cloud point is also an important property of bioethanol fuel, also it is a criterion for low temperature performance of a fuel. Cloud point is the lowest temperature at which a cloud of wax crystals first appear in the fuel when it is cooled (Lenihan et al., 2010). The cloud point of bioethanol from yam peels is $19^{\circ} \mathrm{c}$ while that of bambara nut shells is $20^{\circ} \mathrm{c}$ which are in agreement with the ASTM standard $\left(23^{\circ} \mathrm{c}\right)$. This properties help to show the behavior of the bioethanol under a specified climate setting. 
The pour point is the lowest temperature at which the fuel or bioethanol cannot be moved (freezing point). These properties are related to the use of bioethanol in the cold temperate regions especially in hail region or snow region (Lenihan et al., 2010). The pour point was determined according to ASTM D97 and the value obtained as previewed in table 3 were $-25^{\mathrm{O}} \mathrm{c}$ and $-24^{\mathrm{O}} \mathrm{c}$ which is lower than the standard pour point of ethanol $\left(5.30^{\mathrm{O}} \mathrm{c}\right)$. The result indicates that the bioethanol produced can be used even in Polar Regions where the atmospheric temperature is not less than $5^{\mathrm{O}} \mathrm{c}$.

Octane number is the anti- knock index of a fuel, the higher the octane number, the lesser the anti-knock effect and vice-versa, Reported by Sheikh (2016). The value of the octane number obtained as previewed in table 3 were 101 and 104 respectively which are in agreement with the ASTM D97 standard which is 99.

It can be referred from the various analysis conducted on the bioethanol produced that the properties of the bioethanol produced compared favorably with some of the properties of ethanol. The variation in some of the properties can be attributed to the nature of the feedstock (yam peels and Bambara nut shells) used in this study.

The Fourier transform infrared spectrophotometer (FTIR) showed the presence of peaks range between $1750 \mathrm{~cm}^{-1}$ and $1512 \mathrm{~cm}^{-1}, 2200 \mathrm{~cm}^{-1}$ and $2000 \mathrm{~cm}^{-1}, 3000 \mathrm{~cm}^{-1}$ and $2800 \mathrm{~cm}^{-1}, 3450 \mathrm{~cm}^{-1}$ and $3371 \mathrm{~cm}^{-1}$ which suggests the presences of $\mathrm{NH}$ bend, $\mathrm{C}=\mathrm{N}, \mathrm{C}-\mathrm{H}$ stretch and $\mathrm{O}-\mathrm{H}$ stretch for the first sample. While for the second sample transform infrared spectrophotometer (FTIR) showed the presence of peaks range between $1750 \mathrm{~cm}^{-1}$ and $1512 \mathrm{~cm}^{-1}, 3000 \mathrm{~cm}^{-1}$ and $2800 \mathrm{~cm}^{-1}$, $3450 \mathrm{~cm}^{-1}$ and $3371 \mathrm{~cm}^{-1}$ which suggests the presences $\mathrm{Of} \mathrm{N}-\mathrm{H}$ bend, C-H stretch and $\mathrm{O}-\mathrm{H}$ stretch. Both the results suggest that all the functional groups present are majorly alcohol $(\mathrm{O}-\mathrm{H})$ at the absorption range.

The results of FTIR spectroscopic analysis are similar to the finding of Piotrowski, et al. (2011) who investigated structural changes in waste lignocellusic materials.

Gc/Ms Analysis Ethyl alcohol was obtained which is the main goal of the research, though other compounds were also present in the entire samples which are due to the presence of other organic compounds in the sample. The process of fermentation and enzymatic activities hinder the formation of the following constituents: propane, butanol and carboximide. Interestingly, most of these compounds present in the end of bioethanol production have fuel potentiality. Propane is a good source of liquid gasoline that belongs to alkane group. It is a three carbon gas which is formed as a result of decomposition of organic matter over a period of time. Propane is a clean and eco-friendly gasoline commonly used in America for cooking, grilling and automobile fuel. Propane emission reaches the standard of clean air set by Environment Protection Agency. 


\section{CONCLUSION AND RECOMMENDATION}

\section{Conclusion}

The aim of this research was to produce bioethanol using lignocellulosic yam peels and bambara nut shells. Pretreatment procedure conducted is dilute acid hydrolysis. Acid hydrolysis offers the advantage of taking a shorter period than that of enzyme hydrolysis. However, enzymes hydrolysis gave high amount of hydrolyzates biomass without requiring any neutralization. The absence of fermentation inhibitors resulted in more bioethanol being produced through enzyme hydrolysis than from acid hydrolysis after fermentation. Ethanol yield could have been higher if the yeast saccharomyces cerevisiae could ferment both pentose and hexose sugars. Dilute acid hydrolysis greatly improves the accessibility of cellulose. It would be beneficial to use $2 \mathrm{M}$ $\mathrm{H}_{2} \mathrm{SO}_{4}$ than $0.25 \mathrm{M}$ to achieve high yield of glucose in sample A (yam peels) and $0.25 \mathrm{M} \mathrm{H}_{2} \mathrm{SO}_{4}$ than $2 \mathrm{M}$ in sample B to attain high yield of glucose since there was not much of a difference in the reduction of the degree of crystalline and the yield of glucose per gram of biomass. Lower temperature were employed in the dilute acid hydrolysis, and alkali neutralization with sodium hydroxide resulted in the highest amount of glucose being present in the hyrolyzates without requiring a further step of concentration which would have increased the cost. Bioethanol production remains one of the most promising possible substituent for fossil based fuel. Therefore, the need to make available, cost effective methods employed in its production if it is to be sustainable.

\section{Recommendation}

Future work in bioethanol production needs to be focused on producing enzymes that are more tolerant to harsh acid conditions or produce glucose faster. The same also applies to fermentation yeasts. 


\section{REFERENCES}

Abdullahi B. R., Solomon B. O., Shauibu B. M and Hassan L. G., (2014). Utalization of rice husks and Groundnut Shells for Bioethanol Production. International Journal of Environmental Science and Development. 5: (4) Pp 367-369.

Adeeyo et al. (2015). Acid Hydrolysis of lignocellulosic content of sawdust to fermentable Sugar for Ethanol production. International journal of scientific and engineering research, 6.

Croocks R. J., (2006). Comparative Biofuel Performance Internal Combustion Engines. Biomass Bioenergy. 30: Pp 461-468.

Goh, C. S., and Lee, K. T. (2010). A visionary and conceptual macroalgae-based third generation bioethanol (TGB) biorefinery in Sabah, Malaysia as an underlay for 70

Hendriks, A.T.W.M. and Zeeman, G., (2009). Pretreatments to enhance the Digestibility oflignocellulosic Biomass. Bioresour. Technol.100: Pp 10-18.

Lenihan, P., Orozco, A., Neill, E. O., Ahmad, M. N. M., Rooney, D. W., \& Walker, G. M. (2010). Dilute acid hydrolysis of lignocellulosic biomass. Chemical Engineering Journal Journal, 156, 395-403. https://doi.org/10.1016/j.cej.2009.10.061

Mathew, A. K. (2013). Dilute acid pre-treatment of oilseed rape straw for bioethanol production. Renewable Energy, 36: 2424-2432.

Mohd Azhar, S. H., Abdulla, R., Jambo, S. A., Marbawi, H., Gansau, J. A., Mohd Faik, A. A., \& Rodrigues, K. F. (2017). Yeasts in sustainable bioethanol production: A review. Biochemistry and Biophysics Reports, 10: Pp 52-61. https://doi.org/10.1016/j.bbrep.2017.03.003

Mosier, N., Wyman, C., Dale, B., Elander, R., Lee, Y.Y., Holtzapple, M. and Ladisch, M.2005. Features of promising technologies for pretreatment of lignocellulosic biomass. Bioresource Technology 96(6), 673-686.

Nair, R. B., Lennartsson, P. R., \& Taherzadeh, M. J. (2017). Bioethanol Production From Agricultural and Municipal Wastes. Current Developments in Biotechnology and Bioengineering. Elsevier. Pp 8https://doi.org/10.1016/B978-0-444-63664-5.00008-3

Rabah, A., Oyeleke, S., Manga S. and Hassan L. G., (2011). Dilute acid pretreatment of millet and guinea corn husks for bioethanol production. International Research Journal of Microbiology. 2 (11): Pp 460-465.

Ranken (1984),

Rittmann B. E., Torres C. I. and Kato Marcus A., (2008). Perspectives on microbial fuel cells and other biomass-based renewable energy technologies.Emerging Technologies, V. Shah, ed, Springer, in press.

Sheikh, R. A., Al-bar, O. A., Soliman, Y. M. A., Sheikh, R. A., Al-bar, O. A., and Soliman, Y. 
International Journal of Advanced Academic Research (Sciences, Technology and Engineering) | ISSN: 2488-9849

Journal DOI: 10.46654/ij.24889849

Vol. 6, Issue 10 (October, 2020) | www.ijaar.org

Article DOI: 10.46654/ij.24889849.e61012

M. A., (2016). Biochemical studies on the production of biofuel ( bioethanol ) from potato peels wastes by Saccharomyces cerevisiae : effects of fermentation periods and nitrogen source concentration. Biotechnology \& Biotechnological Equipment. Pp 13102818.

Soibam, H., Ayam, V. S., Mitra, S., Harvest, P., Crops, H., \& Krishiviswavidyalaya, B. C. (2017).morphological characteristics of yam cultivars at different stages of growth , development and harvesting.Int. J. Agricult. Stat. Sci., 13(2), 499-505. 